\title{
Human Neutrophils Increase Expression of C3bi as well as C3b Receptors upon Activation
}

\author{
Melvin Berger, John O'Shea, Alan S. Cross, \\ Thomas M. Folks, Thomas M. Chused, Eric J. Brown, \\ and Michael M. Frank \\ Allergy-Immunology Service and Department of Bacterial \\ Diseases, Walter Reed Army Medical Center, Washington, DC \\ 20307 and National Institute of Allergy and Infectious Diseases, \\ National Institutes of Health, Bethesda, Maryland 20205
}

bstract. We used monoclonal antibodies and flow cytometry to study the expression of the receptors for the complement fragments C3bi (CR3) and C3b (CR1) on human polymorphonuclear neutrophil leukocytes (PMN). Expression of both receptors was minimal on cells stained in anticoagulated whole blood incubated at $0^{\circ}$ or $37^{\circ} \mathrm{C}$. PMN isolated with Percoll density gradients and held at $0^{\circ} \mathrm{C}$ also had only minimal expression of both receptors. With the isolated cells, however, a spontaneous increase in expression of both receptors occurred upon warming to $37^{\circ} \mathrm{C}$. This did not represent complete expression of either receptor since additional increments in surface expression could be induced upon stimulation with $\mathrm{N}$-formyl-methionylleucyl-phenylalanine or Raji cell supernatant. The increases in complement receptor (CR) expression appeared to be specific since there were no changes in expression of the Fcy receptor or $\beta$-2-microglobulin under any of these conditions. The increased CR expression seems to involve translocation from an intracellular pool since it is complete within minutes and is not blocked by puromycin or cycloheximide. These results demonstrate that both CR3 and CR1 expression increase rapidly upon activation of PMN and that isolated cells can be

The opinions and assertions contained herein are the privately held views of the authors and do not represent official policy of the U.S. Army or Department of Defense.

Reprint requests should be addressed to Dr. Berger, Department of Pediatrics, Case Western Reserve University School of Medicine, Rainbow, Babies and Childrens Hospital, Cleveland, $\mathrm{OH} 44106$.

Received for publication 30 March 1984.

J. Clin. Invest.

(c) The American Society for Clinical Investigation, Inc.

0021-9738/84/11/1566/06 $\$ 1.00$

Volume 74, November 1984, 1566-1571 used to study this phenomenon, which may be a critical part of neutrophil function in vivo.

\section{Introduction}

Efficient phagocytosis requires the participation of opsonins, serum proteins such as IgG, and the complement fragments $\mathrm{C} 3 \mathrm{~b}$ and $\mathrm{C} 3 \mathrm{bi}$, that become bound to the surface of microorganisms or other particles and interact with specific receptors on phagocytic cells to promote adherence and ingestion of the organisms. Increased expression of receptors for these proteins on the surface of the phagocytes would be expected to result in increased avidity for the opsonized particles and enhanced phagocytosis.

Kay et al. first reported in 1979 that exposure of polymorphonuclear neutrophil leukocytes (PMN) to chemotactic factors causes enhanced rosette formation with complement-coated sheep erythrocytes and postulated that this might be important in augmenting the activity of the PMN at inflammatory sites in vivo (1). Rosette assays, however, may be influenced by a variety of factors, so it was not possible to attribute the observed enhancement to an increased number of receptors, per se. Fearon and Collins used antibody to the $\mathrm{C} 3 \mathrm{~b}$ receptor (CR1) ${ }^{1}$ and flow cytometry to study the expression of that protein directly. They observed that PMN in anticoagulated blood express relatively few $\mathrm{C} 3 \mathrm{~b}$ receptors but that this number increases rapidly upon incubation with C5a or f-met-leu-phe (2). With isolated PMN, however, the surface expression of $\mathrm{C} 3 \mathrm{~b}$ receptors increases rapidly upon incubation at $37^{\circ} \mathrm{C}$ even in the absence of added stimuli, and reaches a maximum of $\sim 40,000$ receptors per cell. They concluded that the effects of activators on expression of the C3b receptors could not be demonstrated with isolated PMN. In contrast, Berger and Cross recently demonstrated that exposure of isolated PMN to

1. Abbreviations used in this paper: $\mathrm{C} 3$, the third component of human complement; CR1, type 1 complement receptor; CR3, type 3 complement receptor; FITC, fluorescein isothiocyanate; f-mlp, $\mathrm{N}$-formylmethionyl-leucyl-phenylalanine. 
supernatants of Raji lymphoblastoid cells causes increased $\mathrm{C} 3 \mathrm{~b}$-mediated rosetting due to the expression of an increased number of surface receptors with the same apparent affinity for soluble ${ }^{125} \mathrm{I}-\mathrm{C} 3 \mathrm{~b}$ (3).

In addition to $\mathrm{C} 3 \mathrm{~b}$, the further cleavage product, $\mathrm{C} 3 \mathrm{bi}$, has been shown to have important opsonic activity (4) that is mediated by a distinct cell surface receptor termed CR3. Although no analysis of the binding of soluble C3bi to CR3 has yet been performed, recent studies suggest that the monoclonal antibodies $O K M^{*} 1$ and $\mathrm{M} 1 / 70$ recognize the membrane protein that is $\operatorname{CR} 3(5,6)$ and is distinct from CR1. In the present studies we used flow cytometry to assess the binding of monoclonal antibodies to the $\mathrm{C} 3 \mathrm{~b}$ and $\mathrm{C} 3 \mathrm{bi}$ receptors of human PMN in whole blood and after isolation. The results indicate that neither CR1 nor CR3 is prominently expressed on resting cells in whole blood, but the expression of both receptors is markedly enhanced following incubation of isolated PMN as well as cells in fresh whole blood with a variety of activating stimuli.

\section{Methods}

Leukocyte isolation and incubation. Freshly drawn peripheral blood from normal donors was anticoagulated with heparin at a final concentration of $20 \mathrm{U} / \mathrm{ml}$ or EDTA at $10 \mathrm{mM}$. PMN were isolated using density gradients of Percoll (Pharmacia Fine Chemicals, Piscataway, $\mathrm{NJ}$ ) made isotonic with phosphate-buffered saline, $\mathrm{pH} 7.4$, as described by Harbeck et al. (7), except that centrifugation was performed at $14^{\circ} \mathrm{C}$ for $17 \mathrm{~min}$. For comparison, in one experiment, PMN were isolated by centrifugation of heparinized peripheral blood through Ficoll-Hypaque density gradients followed by dextran sedimentation (8). Erythrocytes were removed using two cycles of lysis with ice-cold $0.2 \% \mathrm{NaCl}$ followed by $1.6 \% \mathrm{NaCl}$. Leukocytes were washed an additional time using Hank's balanced salt solution (HBSS) without calcium, magnesium, or phenol red. Such preparations contained $>95 \%$ neutrophils and $>98 \%$ of the cells excluded trypan blue. PMN were incubated at $10^{6} / \mathrm{ml}$ in RPMI 1640 with L-glutamine and $25 \mathrm{mM}$ Hepes (Gibco, Grant Island, NY) supplemented with $0.1 \%$ gelatin and $5 \mathrm{mM}$ EDTA at $37^{\circ} \mathrm{C}$. In some experiments, whole blood was incubated at $0^{\circ}$ or $37^{\circ} \mathrm{C}$ before addition of sufficient amounts of monoclonal antibodies to saturate the available receptors. Incubation was then continued at $4^{\circ} \mathrm{C}$ on a rotator for $30 \mathrm{~min}$. In these experiments, buffy coat cells were obtained after centrifugation at 250 $g$ at $4^{\circ} \mathrm{C}$. Erythrocytes were removed by hypotonic lysis, the leukocytes were washed again in HBSS, stained with fluorescein-isothiocyanate (FITC) conjugate, and prepared for cytometry as described for isolated PMN, below. All washes were performed by centrifugation at $200 \mathrm{~g}$ for $10 \mathrm{~min}$ at $4^{\circ} \mathrm{C}$.

The synthetic chemoattractant, $N$-formyl-methionyl-leucyl-phenylalanine (f-mlp), was obtained from Peninsula Laboratories, Belmont, $\mathrm{CA}$, and stored at $-70^{\circ} \mathrm{C}$ as a $10^{-3} \mathrm{M}$ stock solution in dimethyl sulfoxide and diluted to $10^{-6} \mathrm{M}$ for use. Phenylmethyl-sulfonyl fluoride (PMSF), cycloheximide, and puromycin were purchased from Sigma Chemical Co., St. Louis, MO. Raji cells, originally obtained from Dr. A. Theofilopoulos, La Jolla, CA, were maintained in culture and used as a source of cell-free supernatant as previously described (3).

Monoclonal antibodies and flow cytometry. Monoclonal antibody to the human $\mathrm{C} 3 \mathrm{~b}$ receptor was prepared by immunizing BALB/c mice with the purified CR1 protein from human erythrocytes (9), fusion of spleen cells with the SP2/0 myeloma cell line, and cultivation of hybridoma cells as described (10). Positive clones were selected by their ability to inhibit rosette formation between human PMN and C3b-coated sheep erythrocytes (O'Shea, J., E. J. Brown, B. E. Seligman, J. A. Metcalf, M. M. Frank, and J. I. Gallin, manuscript in preparation). Antibody was purified from ascites using octanoic acid (11). This antibody reacted with a 250,000 -mol wt glycoprotein on the surface of human cells that appears to be identical with the human $\mathrm{C} 3 \mathrm{~b}$ receptor described by Fearon (9). Culture supernatant of the M1/70 hybridoma cell line (obtained from American Type Culture Collection, Rockville, MD) was used as a source of monoclonal antibody to the Mac 1 antigen, which has been identified as CR3 (5). The OKM*1 monoclonal antibody, which also appears to be specific for CR3 (6), was obtained from Ortho Pharmaceutical, Raritan, NJ. Monoclonal antibody to the human neutrophil Fc $\gamma$ receptor (12) was purchased from New England Nuclear, Boston, MA. FITC-conjugated monoclonal antibody to human $\beta$-2-microglobulin was purchased from BectonDickinson \& Co., Oxnard, CA, and FITC-conjugated, succinyl-wheat germ agglutinin was obtained from Vector Laboratories, Inc., Burlingame, CA. FITC-conjugated $\mathrm{F}\left(\mathrm{ab}^{\prime}\right)_{2}$ fragments of goat anti-rat IgG and anti-mouse IgG were purchased from Cappel Laboratories, Cochranville, PA. All antibodies and conjugates were centrifuged at $110,000 \mathrm{~g}$ for 15 min in an airfuge (Beckman Instruments, Inc., Fullerton, CA) before each use.

After incubation, neutrophils were divided into aliquots of $10^{6}$ cells each, washed with ice-cold HBSS containing $0.1 \%$ bovine serum albumin, $0.05 \% \mathrm{NaN}_{3}$, and $10^{-4} \mathrm{M}$ phenyl methyl sulfonyl fluoride, and resuspended in $50 \mu \mathrm{l}$ of the same medium. Monoclonal antibodies were added in excess, as determined in preliminary saturation experiments, and the mixtures were incubated at $4^{\circ} \mathrm{C}$ for $30 \mathrm{~min}$. After washing twice, excess FITC-F( $\left(a^{\prime}\right)_{2}$ anti-rat IgG (for Mac 1) or antimouse IgG (for other monoclonal antibodies) was added and incubation was continued for an additional $30 \mathrm{~min}$. The stained cells were washed three times and were suspended in phosphate-buffered saline with $0.05 \% \mathrm{NaN}_{3}$ and held on ice until examination in the flow cytometer.

The final concentration of FITC-succinyl wheat germ agglutinin was chosen to avoid agglutination of the cells. When this conjugate and the FITC-anti- $\beta$-2-microglobulin were used, only a single 30 -min incubation and series of three washes were employed.

For isolated PMN, determination of cell fluorescence and volume was carried out using a FACS analyzer (Becton-Dickinson \& Co.) standardized with $7.8-\mu \mathrm{m}$-diameter fluorescent microbeads. Data on 10,000 cells were collected for each sample. For experiments using buffy coat cells a FACS IV (Becton-Dickinson \& Co.) was employed and 50,000 cells were examined. Fluorescence of PMN was selectively analyzed based on their light-scattering properties. Fluorescent channels determined in a logarithmic mode were converted to their linear equivalents and samples were compared by their arithmetic means.

Purified M1/70 and anti-CR1 antibodies were radiolabeled using $\mathrm{Na}{ }^{125} \mathrm{I}$ and Iodobeads (Pierce Chemical Co., Rockford, IL) and used for direct binding studies with isolated PMN as previously described (3). Nonspecific binding was determined in tubes containing a 100fold excess of unlabeled antibody.

\section{Results}

$C 3 b i$ and $C 3 b$ receptor expression by $P M N$ in whole blood and after isolation. Neutrophils that had been stained with anti- 

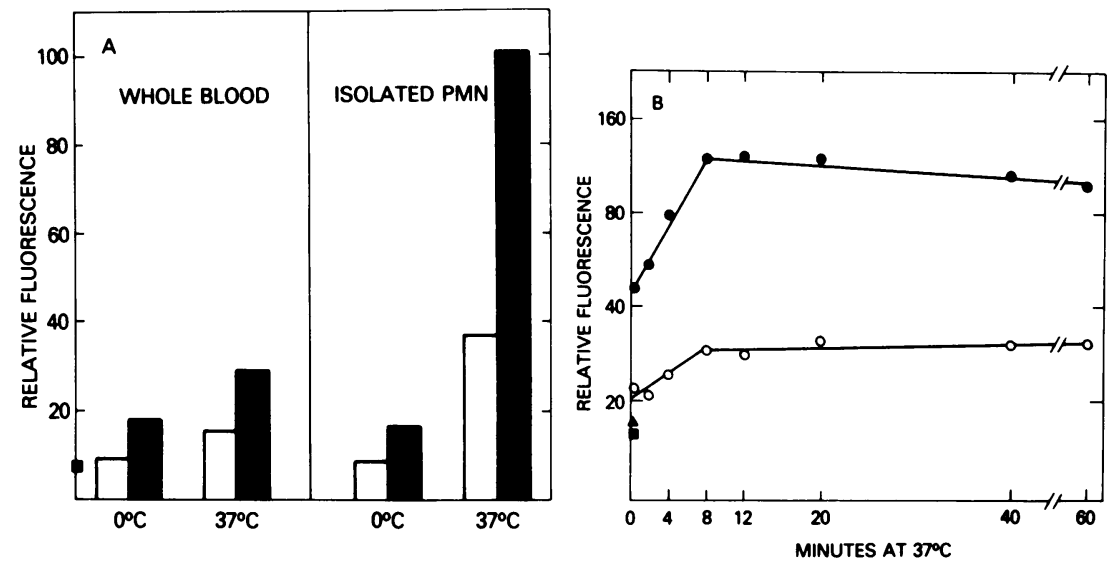

Figure 1. $(A)$ Expression of $\mathrm{C} 3 \mathrm{~b}$ and $\mathrm{C} 3 \mathrm{bi}$ receptors on PMN in whole blood (left panel) or after isolation (right panel) at $0^{\circ}$ and $37^{\circ} \mathrm{C}$. Whole blood anticoagulated with EDTA or isolated PMN was incubated at the designated temperature for $60 \mathrm{~min}$, then reacted with monoclonal antibody to the CR1 ( $\square$ ) or CR3 ( $\square$ ) as described in Methods. Fluorescence was determined using the FACS IV. Results are expressed as the arithmetic mean relative fluorescence for 10,000 cells. Mean fluorescence for unstained cells is indicated by the solid box at the ordinate. $(B)$ Time course of increase in expression of $\mathrm{C} 3 \mathrm{~b}$ and $\mathrm{C} 3 \mathrm{bi}$ receptors by isolated PMN kept on ice and then incubated at $37^{\circ} \mathrm{C}$ for the time indicated. Fluorescence was determined using the FACS analyzer. Results are expressed as the arithmetic mean relative fluorescence for 10,000 cells. Mean fluorescence for cells not reacted with any antibody ( $\square$ ) and for cells incubated with FITC conjugates only ( $\Delta$ ) are shown along the ordinate.

CR1 or anti-CR3 in whole blood before centrifugation to obtain buffy coat demonstrated slight fluorescence above that of unstained cells and there was no appreciable difference in fluorescence if the unfractionated blood was preincubated at $0^{\circ}$ or $37^{\circ} \mathrm{C}$ for $1 \mathrm{~h}$ before reaction with the antibodies (Fig. 1 $A$ ). These results suggest that both the $\mathrm{C} 3 \mathrm{~b}$ and $\mathrm{C} 3 \mathrm{bi}$ receptors are minimally expressed on resting PMN in whole blood. Isolation of the PMN using Percoll density gradients and hypotonic lysis to remove erythrocytes did not alter this minimal receptor expression, since there was no increase in the fluorescence of the isolated cells stained with antibody to CR 1 or $\mathrm{CR} 3$ when the isolated $\mathrm{PMN}$ were maintained at $0^{\circ} \mathrm{C}$. Direct-binding studies using ${ }^{125} \mathrm{I}$-labeled antibodies and Scatchard analysis revealed $6,700 \pm 850$ (mean \pm SEM for three determinations) binding sites per cell for anti-CR1 and $17,222 \pm 1,714$ sites for anti-CR3 (nine determinations) on isolated PMN maintained at $0^{\circ} \mathrm{C}$. When the isolated PMN were warmed to $37^{\circ} \mathrm{C}$ a modest increase in the staining with anti-CR1 and anti-CR3 occurred within 5 to $10 \mathrm{~min}$ (Fig. $1 B)$.

To determine the possible effects of the isolation procedure on receptor expression, heparinized blood from two donors was divided into paired aliquots and PMN were isolated concurrently from one aliquot by the Percoll method and from the other aliquot by standard Ficoll-Hypaque centrifugation (8) followed by dextran sedimentation at room temperature. Portions of these cells were then incubated at $0^{\circ}$ or $37^{\circ} \mathrm{C}$ and stained with anti-CR 1 and anti-CR3. No differences in the expression of either receptor were noted on cells incubated at either temperature regardless of the isolation technique that had been employed.

Activation-induced increases in CR1 and CR3 expression. The apparently temperature-dependent increase in the availability of the complement receptors on isolated cells warmed to $37^{\circ} \mathrm{C}$ resulted in a uniform shift in the fluorescence intensity of the whole population of cells (Fig. 2). The extent of this spontaneous increase in availability of CR1 and CR3 when the isolated cells were rewarmed varied somewhat between individuals and when the same individual was studied on different occasions, but did not represent maximal expression of either of the complement receptors. This is demonstrated by the large increase in fluorescence intensity of cells incubated in Raji cell supernatant compared with control medium at $37^{\circ} \mathrm{C}$ as shown in Fig. 2. Similar shifts in fluorescence occurred when f-mlp was added to the control medium at $37^{\circ} \mathrm{C}$ (Table I). The magnitude of the increase in CR1 and CR3 in response to f-mlp was similar for PMN prepared by the Percoll technique and the traditional method employing dextran sedimentation and Ficoll-Hypaque centrifugation.

When the OKM*1 antibody, which apparently recognizes

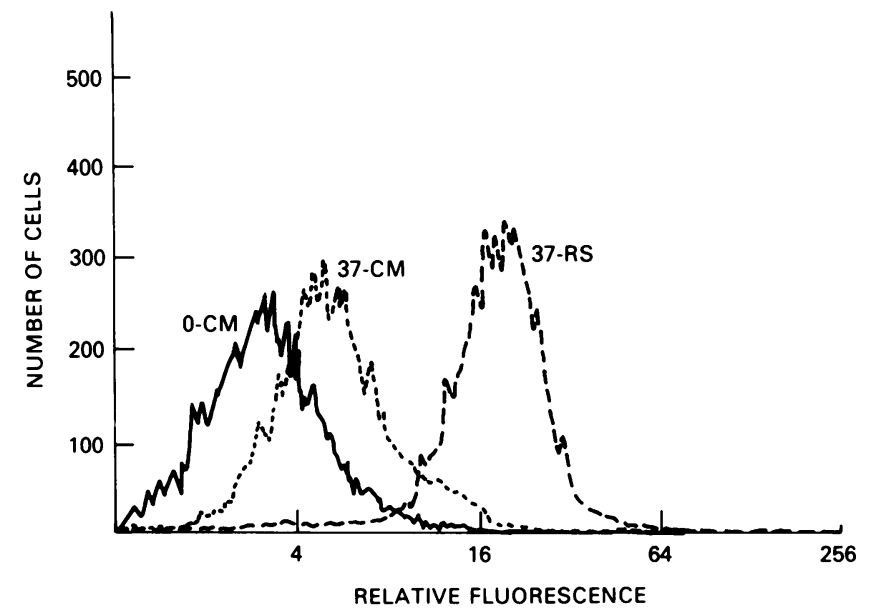

Figure 2. Fluorescence histograms for isolated PMN incubated at $0^{\circ} \mathrm{C}$ in control medium (0), $37^{\circ} \mathrm{C}$ in control medium (CM), and $37^{\circ} \mathrm{C}$ in Raji cell supernatant (RS), then reacted with $\mathrm{M} 1 / 70$ followed by FITC anti-rat IgG to assess CR3 expression. True relative (arithmetic) fluorescence values are shown on the abscissa. 
Table I. Relative Fluorescence

\begin{tabular}{|c|c|c|c|c|c|}
\hline \multirow[b]{2}{*}{ Incubation } & \multicolumn{5}{|l|}{ Antigen } \\
\hline & FcR & $\mathrm{B}_{2} \mathbf{M}$ & CRI & Mac 1 & WGA \\
\hline $37^{\circ} \mathrm{C}$ & $120 \pm 17$ & $108 \pm 11$ & $207 \pm 27$ & $303 \pm 51$ & $201 \pm 13$ \\
\hline f-mlp & $123 \pm 14$ & $97 \pm 10$ & $306 \pm 68$ & $671 \pm 149$ & $211 \pm 38$ \\
\hline $\begin{array}{l}\text { Raji Supernatant } \\
n=\end{array}$ & $\begin{array}{l}100 \pm 21 \\
(5)\end{array}$ & $\begin{array}{l}102 \pm 20 \\
\text { (3) }\end{array}$ & $\begin{array}{l}306 \pm 48 \\
(6)\end{array}$ & $\begin{array}{l}685 \pm 113 \\
(6)\end{array}$ & $\begin{array}{l}212 \pm 42 \\
(3)\end{array}$ \\
\hline
\end{tabular}

Results are expressed as the arithmetic mean \pm SEM fluorescence of 10,000 PMN incubated as indicated and stained for the antigen noted expressed as percent of the arithmetic mean fluorescence of the same antigen on PMN maintained at $0^{\circ} \mathrm{C}$ in control medium. Compared with $\mathrm{CR} 1$ on PMN held at $0^{\circ} \mathrm{C}$, the relative fluorescence intensities for the other antigens on PMN maintained at $0^{\circ} \mathrm{C}$ were: FcR, 1,280 $240 \%$; $\mathrm{B}_{2} \mathrm{M}, 1,380 \pm 190 \%$; Mac 1, 170 $10 \%$; and binding sites for succinylated wheat germ agglutinin (WGA), $770 \pm 300 \%$. Number of experiments $(n)$ are indicated by the numbers in parentheses.

an epitope on CR3 that is different from the Macl antigen (6), was used instead of the M1/70 monoclonal, essentially identical results were obtained for PMN in whole blood as well as for isolated cells.

Specificity of membrane receptor and surface antigen changes upon activation. To determine the possible specificity of the membrane changes in response to f-mlp and Raji supernatant, we examined the expression of the $\mathrm{Fc} \gamma$ receptor, of $\beta-2$ microglobulin, and of the binding sites for succinyl-wheat germ agglutinin after incubation with these stimuli. The results (Table I) clearly indicate that increased expression of both $\mathrm{CR} 1$ and $\mathrm{CR} 3$ occurs on warming of the isolated cells to $37^{\circ} \mathrm{C}$ but that additional large increments in expression occur when the cells are stimulated. The number of binding sites for succinyl-wheat germ agglutinin also increased at $37^{\circ} \mathrm{C}$, but did not show additional increments in expression upon stimulation. The expression of the $\mathrm{Fc} \gamma$ receptor resulted in very bright staining of the cells maintained at $0^{\circ} \mathrm{C}$ and did not show further enhancement at $37^{\circ} \mathrm{C}$ or in response to the stimuli, a pattern that was shared by the $\beta$-2-microglobulin. Addition of cycloheximide or puromycin at $10 \mu \mathrm{g} / \mathrm{ml}$ to the media did not affect the increase in expression of CR1 or CR3 observed under any of these conditions (data not shown), suggesting that synthesis of new receptor protein is not required.

Stability of receptors once they are expressed on the cell surface. To determine the stability of surface receptor expression after activation, we incubated $\mathrm{PMN}$ at $0^{\circ} \mathrm{C}$ and at $37^{\circ} \mathrm{C}$ with or without $\mathrm{f}-\mathrm{mlp}$ for $\mathbf{4 0} \mathrm{min}$ in order to allow both the spontaneous, temperature-dependent increase in receptor expression as well as the additional increment due to activation. Aliquots of the cells from each of the incubations were then washed twice at $4^{\circ} \mathrm{C}$ and reincubated for an additional $40 \mathrm{~min}$ at $0^{\circ}$ or $37^{\circ} \mathrm{C}$. Another aliquot from each incubation was left alone without washing. As seen in Fig. 3, there was a twofold increase in expression of both CR1 and CR3 with incubation at $37^{\circ} \mathrm{C}$ and an additional threefold enhancement in expression of both receptors in the presence of $10^{-6} \mathrm{M} \mathrm{f}$-mlp. Cells originally held at $37^{\circ} \mathrm{C}$ and then washed at $4^{\circ} \mathrm{C}$ and reincubated at $0^{\circ}$ or $37^{\circ} \mathrm{C}$ were not distinguishable from cells maintained continuously at $37^{\circ} \mathrm{C}$ (middle panel), indicating that there was no net loss of either CR1 or CR3 once they had been expressed on the surface. When PMN incubated with f-mlp were washed at $4^{\circ} \mathrm{C}$ and then reincubated without $\mathrm{f}-\mathrm{mlp}$, the surface expression of both receptors remained constant on cells reincubated at $37^{\circ} \mathrm{C}$, and there was only a mild decrement in expression of both receptors on cells reincubated at $0^{\circ} \mathrm{C}$ (right panel). These results clearly indicate that once a cell increases its expression of $\mathrm{CR} 1$ and $\mathrm{CR} 3$, this phenotype remains stable.

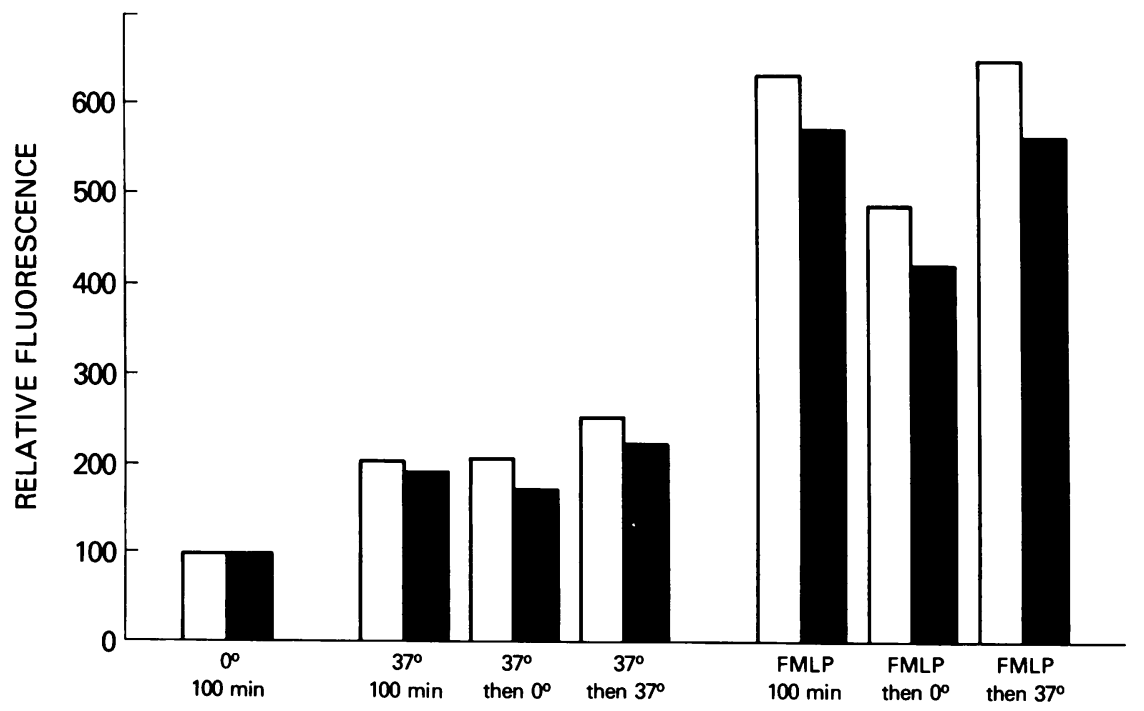

Figure 3. Stability of surface receptor expression after activation. Identical tubes containing 2.5 $\times 10^{6}$ purified $\mathrm{PMN}$ were kept on ice for 100 $\min \left(0^{\circ} \mathrm{C}, 100 \mathrm{~min}\right.$ : pair of bars at left), or kept at $37^{\circ} \mathrm{C}$ for $100 \mathrm{~min}\left(37^{\circ} \mathrm{C}, 100 \mathrm{~min}\right.$ : middle group, left pair) or for $40 \mathrm{~min}$, followed by two 10 -min washes at $4^{\circ} \mathrm{C}$ then reincubated for an additional $40 \mathrm{~min}$ on ice $\left(37^{\circ}\right.$ then $\left.0^{\circ} \mathrm{C}\right)$ or at $37^{\circ} \mathrm{C}\left(37^{\circ} \mathrm{C}\right.$ then $37^{\circ} \mathrm{C}$ : middle group, right pair). Tubes in the right group were handled in the same way but contained $10^{-6} \mathrm{M} \mathrm{f}-\mathrm{mlp}$ in the first incubations. At the end of the entire incubation period, cells were stained for CR 1 ( $\square$ ) and CR3 expression ( $(\square)$ as described in Methods. Results are expressed as the arithmetic mean fluorescence of 10,000 cells expressed as percent of the arithmetic mean fluorescence of PMN maintained at $0^{\circ} \mathrm{C}$ for the entire period and stained for CR1 and CR3, respectively. 


\section{Discussion}

In this study we used monoclonal antibodies and flow cytometry to assess the expression of receptors for the important opsonins $\mathrm{C} 3 \mathrm{~b}$ and $\mathrm{C} 3 \mathrm{bi}$ on the surface of human PMN. The results indicate that the PMN in whole blood express relatively few receptors for $\mathrm{C} 3 \mathrm{~b}$ or $\mathrm{C} 3 \mathrm{bi}$. With cells isolated using Percoll gradients and maintained at $0^{\circ} \mathrm{C}$ the results are very similar. Quantitative analysis demonstrated that there are $\sim 7,000 \mathrm{CR} 1$ sites and 17,000 CR3 sites on these isolated cells. These findings confirm the observations of Fearon and Collins (2) on the behavior of the $\mathrm{C} 3 \mathrm{~b}$ receptor, $\mathrm{CR} 1$, and extend them to a second distinct cell surface antigen that is believed to be the C3bi receptor, CR3 $(5,6)$. Our results with isolated cells differ from those of Fearon and Collins since in our studies the isolated PMN expressed only a portion of their CR1 and $\mathrm{CR} 3$ when incubated at $37^{\circ} \mathrm{C}$ and could continue to respond to stimuli by further increasing membrane expression of these receptors. We cannot presently explain this difference, but it is apparently not due to the reagents or methods used for isolating the neutrophils since we obtained identical increases in receptor expression with cells prepared using Percoll (7) or by conventional Ficoll-Hypaque and dextran sedimentation (8) techniques, and Berger and Cross could demonstrate similar increments in expression of binding sites for ${ }^{125} \mathrm{I}-\mathrm{C} 3 \mathrm{~b}$ (3) on PMN prepared using a modified Ficoll-Hypaque technique that eliminates the need for dextran sedimentation (13).

Kay et al. described the phenomenon of "complement receptor enhancement" by phagocytic cells in response to various stimuli (1) and have suggested that this response may be important in enhancing phagocytic activity of neutrophils at inflammatory sites in vivo. The molecular basis for the observed enhancement has remained controversial, however, since the rosette assays used by Kay et al. cannot distinguish between increased numbers of receptors and other changes that could promote multivalent attachment. Our results clearly demonstrate that several stimuli induced the expression of additional receptors for both $\mathrm{C} 3 \mathrm{~b}$ and $\mathrm{C} 3 \mathrm{bi}$ on isolated PMN as well as on cells in unfractionated blood and suggest that increased receptor expression may be at least partially responsible for the enhanced rosetting reported by Kay et al.

Although the monoclonal antibody we used to quantitate CR1 and the M1/70 antibody to CR3 block the ligand binding sites of these receptors, several lines of evidence suggest that the very low level of receptor expression observed for PMN in whole blood actually represents the absence of these proteins from the cell surface rather than a failure to detect receptors on the surface that are occupied by ligands and therefore not available to the antibodies. It is unlikely that our results for CR1 would be due to occupancy of this receptor by $\mathrm{C} 3$ or C3b since native C3 does not bind to CR1 (14) and C3b is not likely to be generated in the presence of EDTA and at low temperature. Fearon and Collins, who also found extremely low levels of CR1 on PMN in whole blood and after isolation
(2), used a conventional polyvalent antiserum that recognizes $\sim 10$ antigenic sites per ligand binding unit (15); and Berger and Cross used the ligand itself, ${ }^{125} \mathrm{I}-\mathrm{C} 3 \mathrm{~b}$, and found marked increases in CR1 expression upon stimulation of isolated PMN (3). Similar arguments may also be applied to our results for CR3 since its ligand, C3bi, is equally unlikely to be generated in the presence of EDTA at low temperature and since we obtained identical results with the OKM*1 antibody that binds to a site on CR3 remote from the ligand binding site (6).

The rapidity with which the CR1 and CR3 expression increases and the lack of an effect of the protein synthesis inhibitors puromycin and cycloheximide implies that synthesis of new receptor protein is not involved in the increased expression of these receptors. The absence of similar increases in expression of $\beta$-2-microglobulin and $F c \gamma R$ suggests that specific alterations in the cell membrane, rather than generalized increases in the surface area, are occurring. At present, it is not possible to speculate on the mechanisms involved other than to suggest that the additional receptors are likely to be translocated from an intracellular pool to the surface. Although we have not determined whether receptor recycling occurs, the results of Figs. $1 B$ and 3 distinctly show that once PMN are activated, the net increase in surface expression of CR1 and CR3 remains a stable characteristic of the activated cell.

Since isolated PMN are preferable for many types of experiments that explore the biologic role of complement fragments and receptors in phagocytosis, our demonstration that isolated cells can retain their responsiveness to activating stimuli will allow more detailed studies of the mechanism and control of complement receptor expression. The results presented in this paper clearly indicate that isolated PMN can be used for in vitro studies of this phenomenon which is likely to represent an important part of neutrophil function in vivo.

\section{Acknowledgments}

We are grateful to Ms. Carmen Brown for technical assistance and to Ms. Sandra Higgins and Diane Portnoy for assistance with the FACS analyzer. The typescript was prepared by Valerie Miller and Mary Maynard.

This work was supported in part by the Department of Clinical Investigation, Walter Reed Army Medical Center.

\section{References}

1. Kay, A. B., J. Glass, and D. McG. Salter. 1979. Leucoattractants enhance complement receptors on human phagocytic cells. Clin. Exp. Immunol. 38:294-299.

2. Fearon, D. T., and L. A. Collins. 1983. Increased expression of C3b receptors on polymorphonuclear leukocytes induced by chemotactic factors and by purification procedures. J. Immunol. 130:370-375.

3. Berger, M., and A. S. Cross. 1984. Lymphoblastoid cell supernatants increase expression of $\mathrm{C} 3 \mathrm{~b}$ receptors on human polymorpho- 
nuclear leukocytes: direct binding studies with ${ }^{125} \mathrm{I}-\mathrm{C} 3 \mathrm{~b}$. Immunology. 51:431-440.

4. Stossel, T. P., R. J. Field, J. D. Gitlin, C. A. Alper, and F. S. Rosen. 1975. The opsonic fragment of the third component of human complement. J. Exp. Med. 141:1329-1347.

5. Beller, D. I., T. A. Springer, and R. D. Schrieber. 1982. AntiMac 1 selectively inhibits the mouse and human type three complement receptor. J. Exp. Med. 156:1000-1009.

6. Wright, S. D., P. E. Rao, W. C. Van Voorhis, L. S. Craigmyle, K. lida, M. A. Talle, E. F. Westberg, G. Goldstein, and S. C. Silverstein. 1983. Identification of the C3bi receptor of human monocytes and macrophages by using monoclonal antibodies. Proc. Natl. Acad. Sci. USA. 80:5699-5703.

7. Harbeck, R. J., A. A. Hoffman, S. Redecker, T. Biundo, and J. Kurnick. 1982. The isolation and functional activity of polymorphonuclear leukocytes and lymphocytes separated from whole blood on a single Percoll density gradient. Clin. Immunol. Immunopathol. 23:682690.

8. Boyum, A. 1968. Isolation of mononuclear cells and granulocytes from human peripheral blood. Scand. J. Clin. Lab. Invest. 21(Suppl. 97):77-109.

9. Fearon, D. T. 1980. Identification of the membrane glycoprotein that is the $\mathrm{C} 3 \mathrm{~b}$ receptor of the human erythrocyte, polymorphonuclear leukocyte, B lymphocyte and monocyte. J. Exp. Med. 152:20-30.

10. Kohler, G., and C. Milstein. 1975. Continuous cultures of fused cells secreting antibody of predefined specificity. Nature (Lond.). 256:495-497.

11. Steinbuch, M., and R. Audran. 1969. The isolation of IgG from mammalian sera with the aid of caprylic acid. Arch. Biochem. Biophys. 134:279-284.

12. Fleit, H. B., S. D. Wright, and J. C. Unkeless. 1982. Human neutrophil Fc $\gamma$ receptor distribution and structure. Proc. Natl. Acad. Sci. USA. 79:3275-3279.

13. Ferrante, A., and Y. H. Thong. 1979. A rapid one-step procedure for purification of mononuclear and polymorphonuclear leukocytes from human blood using a modification of the hypaqueficoll technique. J. Immunol. Methods. 24:389-393.

14. Berger, M., T. A. Gather, C. H. Hammer, and M. M. Frank. 1981. Lack of binding of human $\mathrm{C} 3$, in its native state, to $\mathrm{C} 3 \mathrm{~b}$ receptors. J. Immunol. 127:1329-1334.

15. Wilson, J. G., W. W. Wong, P. H. Schur, and D. T. Fearon. 1982. Mode of inheritance of decreased C3b receptors on erythrocytes of patients with systemic lupus erythematosus. N. Engl. J. Med. 307:981-986. 